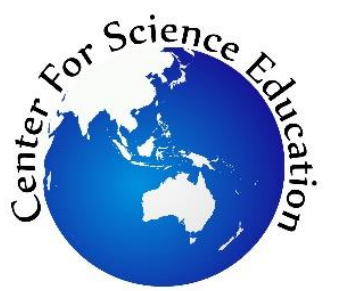

\author{
Tersedia online di EDUSAINS \\ Website: http://journal.uinjkt.ac.id/index.php/edusains
}

EDUSAINS, 13(1), 2021, 25-34

Research Artikel

EDUS:

\title{
DEVELOPING AN E-FLIPBOOK ON ENVIRONMENTAL CHANGE TOPICS TO DEVELOP STUDENTS' DIGITAL LITERACY
}

\author{
PENGEMBANGAN E-FLIPBOOK MATERI PERUBAHAN LINGKUNGAN UNTUK \\ MELATIHKAN LITERASI DIGITAL
}

\author{
Dinda Ainur Rachim, Reni Ambarwati* \\ Fakultas MIPA, Universitas Negeri Surabaya \\ *reniambarwati@unesa.ac.id
}

\begin{abstract}
Digital literacy is one of the abilities that students need to master in the 21 st century. Therefore, this study aims to produce an e-flipbook of environmental change topics to train digital literacy, which is valid, practical, and effective. As a developmental study, it refers to a 4-D model, without a dissemination phase. The material validity was measured based on the validation by material, educational, and information-technology experts. Furthermore, the e-flipbook practicality was measured based on the practitioners and student responses. Also, the effectiveness was measured according to students' digital literacy based on normalized gain score, and the data were descriptive-quantitatively analyzed. The results showed the developed e-flipbook was declared valid based on the eligibility criteria for design, content, and language. Furthermore, it was stated to be practical according to the responses of practitioners and students with the acquisition of very practical and good categories. The e-flipbook was also declared effective with the acquisition of an average score of increasing digital student literacy by 0.7 in the high category. Therefore, it can be concluded that the e-flipbook on environmental change topic is valid, practical, and effective in learning digital literacy.
\end{abstract}

Keywords: digital literacy; e-flipbook; environmental change.

\section{Abstrak}

Literasi digital merupakan salah satu kemampuan yang harus dikuasai peserta didik di abad ke-21. Tujuan penelitian ini adalah menghasilkan e-flipbook materi perubahan lingkungan untuk melatihkan literasi digital kelas X SMA yang layak digunakan, yaitu e-flipbook yang valid, praktis, dan efektif. Penelitian ini merupakan jenis penelitian pengembangan yang mengadaptasi model 4-D namun tahap penyebaran tidak dilakukan. Validitas e-flipbook diukur berdasarkan validasi ahli materi, ahli pendidikan, dan ahli IT. Kepraktisan eflipbook ditinjau berdasarkan respons praktisi dan respons siswa. Keefektifan e-flipbook diukur berdasarkan tes literasi digital peserta didik berdasarkan gain score ternormalisasi. Data dianalisis secara deskriptif kuantitatif. Hasil penelitian menunjukan bahwa e-flipbook yang dikembangkan dinyatakan sangat valid berdasarkan kriteria kelayakan penyajian, isi, dan kebahasaan. E-flipbook yang dikembangkan dinyatakan praktis berdasarkan respons praktisi (guru) dan siswa dengan perolehan kategori sangat praktis dan sangat baik. Eflipbook yang dikembangkan dinyatakan efektif dengan perolehan skor rata-rata peningkatan literasi digital siswa sebesar 0.7 dengan kategori tinggi. Secara keseluruhan e-flipbook materi perubahan lingkungan dinyatakan valid, praktis, dan efektif digunakan dalam pembelajaran untuk melatihkan literasi digital siswa.

Kata Kunci: literasi digital; e-flipbook; perubahan lingkungan.

Permalink/DOI: http:// doi.org/10.15408/es.v13i1.16893 


\section{INTRODUCTION}

Producing teachers who have 21st-century competence, including capabilities in information and communication technology is a real problem in the current field of education (Partnership for 21st Century Learning, 2015). This has also led to the sophistication of technology and increasingly diverse digital information for easy access by anyone or anywhere. Furthermore, digital technology plays an important role in the development of secondary and higher education. This is in line with the current 21 st-century knowledge acquisition where students are required to have innovative skills in technology and information media to be useful in life expertise (Wijaya et al., 2016).

21 st Century skills, including communication abilities, collaboration, critical and creative thinking, as well as problem-solving, are the demands of students (Litbang Kemdikbud, 2013). Therefore, classroom learning using digital literacy methods will create an e-skills character and improve the ability to compete at the international level (Khasanah \& Herina, 2019)

Environmental change is one of the topics in biology learning which can be taught by simultaneously practicing digital literacy to 10thgrade senior high school students. The material illustrates the process of changing the order in the surrounding environment caused by human and natural factors, therefore, the quality decreases or cannot be re-functioned (Pujiyanto, 2008). The material was selected because it has a connection to the environment in daily life (contextual). Through this learning, students are expected to broaden their horizons about environmental issues which can be raised as actual problems to determine the right solution.

Widely circulated information on social media regarding environmental change and pollution requires students to obtain knowledge from reliable sources to formulate solutions. However, the amount of information distributed via the internet makes it difficult to obtain accurately. This inaccuracy can become a conflict between groups to defend their opinions (Gumilar et al.,
2017). Hence, it is necessary to have innovative teaching material and practice the digital literacy of students (Putri \& Ambarwati, 2019a), especially during the Covid-19 pandemic, when the learning process was conducted online. This is consistent with Darmalaksana et al. (2020) that online learning proved to be effective in the Work from Home (WfH). Therefore, e-learning facilitates learners to gain knowledge by independently accessing the internet (Holland, 2019).

One of the choices of innovative teaching materials with an environmentally friendly value (paperless) is an electronic book (e-book). This is the transition from traditional to electronic books with digital features such as video, animation, and sound (Moody, 2010). It has many advantages, one of which is that it can be developed into interactive teaching materials making it easier for students to directly obtain information. Besides, e-books are selected because they are environmentally friendly compared to printed copies (Haris, 2011). Also, it minimizes the excessive use of paper and overcomes the potential for global warming.

Gilster (1997) stated that digital literacy is one's ability to understand and process information from various sources. Therefore, Gilster formulated four student competencies stated to be digital titrated used in this study, namely internet searching, hypertextual navigation, content evaluation, and knowledge assembly.

Meanwhile, in previous studies on digital literacy content, Putri \& Ambarwati (2019a) stated that Biology textbooks for higher education students, in Surabaya and its surrounding, have low digital literacy content. Hence, the development of digital literacy-based textbooks is needed to support the 21st-century teaching and learning process. Furthermore, training students on how to use websites properly or critically, and assimilating, evaluating, as well as integrating information is required. This is urgently needed especially during the Covid-19 period, where all learning is conducted online and the students have free access to the internet.

Based on the problem description above, this study aims to produce e-flipbooks on 
environmental change topic which are valid, practical, and effective to train digital literacy. Hence, teachers can use it as a teaching resource that provides convenience in online learning activities.

\section{METHOD}

This study developed an e-flipbook on environmental change topics to train digital literacy. Furthermore, it referred to the 4D development model (define, design, develop, and disseminate) but only to the stage. The observed variables include validity, practicality, and effectiveness. Also, the limited e-flipbook trial involved 20 students of senior high school by using online classes, which were based on pre-test and post-test design.

The validity of the e-book on environmental change topic to train digital literacy was measured based on validation by education, material, and information-technology experts. Furthermore, the instrument used was a validation sheet that covered the feasibility of design, content, and language. The e-flipbook to train digital literacy was valid when it gets a mode score $\geq 3$.

The practicality of the e-book was reviewed based on the practitioners (teachers) and students' responses. A practitioner questionnaire was filled out by five senior high school biology teachers $(n=5)$ while the students were filled by twenty students after learning $(n=20)$. Therefore, the eflipbook was declared practical when the practitioner (teacher) responses obtain a mode score of $\geq 3$ and the positive student response reaches $\geq 61 \%$.

Meanwhile, the e-book effectiveness was measured by using instruments in the form of digital literacy tests. The online instruments have eight questions with four digital literacy indicators, namely internet searching, hypertextual navigation, content evaluation, and knowledge assembly. Furthermore, the test was filled out by students before and after learning using the e-flipbook.

The increase in students' digital literacy before and after being given treatment is known by using a normalized gain score $(\mathrm{g})$. The score data were analyzed using the categories in Table 1.

Table 1. Normalized Gain Score (g) Category

\begin{tabular}{cc}
\hline N-gain & Category \\
\hline$(\mathrm{g})>0,7$ & High \\
\hline $0,3>(\mathrm{g})>0,7$ & Medium \\
\hline$(\mathrm{g})<0,3$ & Low \\
\hline
\end{tabular}

\section{RESULTS AND DISCUSSION}

The results were valid, practical, and effective for 10th-grade senior high school students.

The electronic teaching material was developed to achieve the basic competency of this topic and train digital literacy. This e-book contained a description of environmental change topic, which was divided into three chapters, namely environmental change, pollution, and waste recycling. The e-flipbook profile of the topic's material is shown in Figure 1.

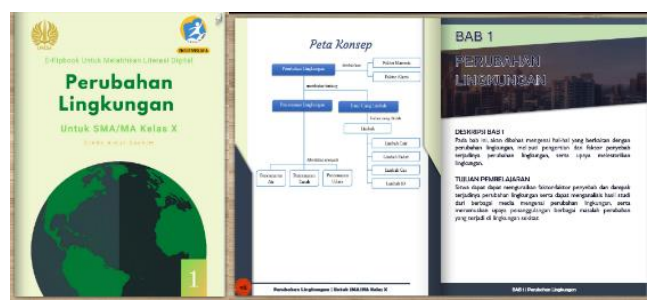

Figure 1. Profile of E-Flipbook on Environmental Change Topic to Train Digital Literacy

The developed material was equipped with pictures, videos, hyperlinks, and questions presented through features to support the concept of environmental change in learning. Besides, the feature was a facility used in training digital literacy and was in the form of Tahukah Kamu, Wawasan Biologi, Mari Berliterasi, Ayo Simpulkan as well as Ayo Berlatih as presented in Table 2. 
Table 2. Features in the E-flipbook

\begin{tabular}{|c|c|c|}
\hline No. & Feature & Description \\
\hline \multirow[t]{2}{*}{1.} & Tahukah Kamu? & \multirow{2}{*}{$\begin{array}{l}\text { This feature facilitates the students watched a video to } \\
\text { practice the ability to access tools and digital facilities } \\
\text { (internet searching). }\end{array}$} \\
\hline & 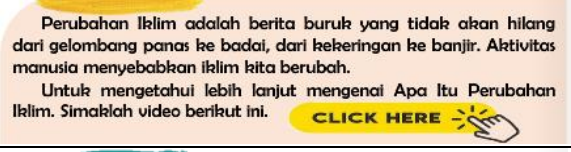 & \\
\hline \multirow[t]{2}{*}{2.} & Wawasan Biologi & \multirow{2}{*}{$\begin{array}{l}\text { This feature provides additional information to train } \\
\text { students to formulate stages of information searching } \\
\text { (internet searching) and identify hypertext guidance } \\
\text { in the web browser (hypertextual navigation). }\end{array}$} \\
\hline & $\begin{array}{l}\text { Untuk memperdalam pemahaman dan mengetahui informasi } \\
\text { tambahan mengenai kerusakan lingkungan yang menyebabkan } \\
\text { perubahan iblim, Kolian bisa mengakses website di bawah ini. } \\
\text { CLICK HERE }\end{array}$ & \\
\hline \multirow[t]{3}{*}{3.} & Mari Berliterasil & \multirow{3}{*}{$\begin{array}{l}\text { This feature facilitates students searching for trusted } \\
\text { information sources on the internet to practice the } \\
\text { ability to evaluate the validity of information content } \\
\text { (content evaluation) and manage information in the } \\
\text { form of facts and opinions found online (knowledge } \\
\text { assembly). }\end{array}$} \\
\hline & 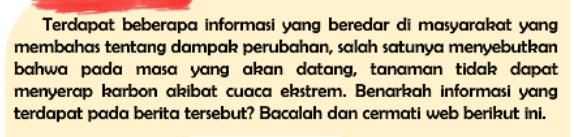 & \\
\hline & CLICK HERE “' 'Ḿ & \\
\hline \multirow[t]{2}{*}{4.} & Ayo Simpulkant & \multirow{2}{*}{$\begin{array}{l}\text { This feature contains several questions in the form of } \\
\text { summarized information from the results of activities } \\
\text { that have been carried out. }\end{array}$} \\
\hline & $\begin{array}{l}\text { Berdasarkan materi yang telah Kalian pelajari, cobalah untuk } \\
\text { menyimpulkan konsep yang telah Kalian pelajari. Kalian bisa } \\
\text { mengakses web dibawah ini. } \\
\text { CLICK HERE - }\end{array}$ & \\
\hline \multirow[t]{2}{*}{5.} & Ayo Berlatih! & \multirow{2}{*}{$\begin{array}{l}\text { This feature contains several questions about the entire } \\
\text { material in the chapters that have been studied } \\
\text { previously. }\end{array}$} \\
\hline & 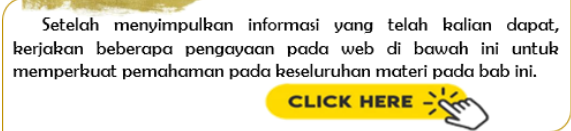 & \\
\hline
\end{tabular}

The validation results of each aspect obtained mode 4 with a very valid category (Table 3 ). This showed that the e-flipbooks developed by the research team were included in the very valid category

Table 3. Recapitulation of E-flipbook Validation Results on Environmental Change Topic to Train Digital Literacy

\begin{tabular}{|c|c|c|c|}
\hline Num. & $\begin{array}{c}\text { Assessment } \\
\text { Aspects }\end{array}$ & $\begin{array}{l}\text { Mode of } \\
\text { Score }\end{array}$ & Category \\
\hline \multicolumn{4}{|c|}{ Design } \\
\hline 1. & Display Quality & 4 & Very valid \\
\hline 2. & Layout Quality & 4 & Very valid \\
\hline 3. & Text Quality & 4 & Very valid \\
\hline 4. & Figure Quality & 4 & Very valid \\
\hline 5. & Video Quality & 4 & Very valid \\
\hline 6. & E-flipbook Quality & 4 & Very valid \\
\hline \multicolumn{4}{|c|}{ Content } \\
\hline 7. & $\begin{array}{l}\text { Quality of Material } \\
\text { Concepts }\end{array}$ & 4 & Very valid \\
\hline 8. & Title of E-flipbook & 4 & Very valid \\
\hline 9. & Introduction & 4 & Very valid \\
\hline 10. & $\begin{array}{l}\text { Instructions for } \\
\text { Use of E-flipbook }\end{array}$ & 4 & Very valid \\
\hline 11. & $\begin{array}{l}\text { Characteristics of } \\
\text { E-flipbook }\end{array}$ & 4 & Very valid \\
\hline 12. & Content & 4 & Very valid \\
\hline 13. & References & 4 & Very valid \\
\hline 14. & Glossary & 4 & Very valid \\
\hline 15. & $\begin{array}{l}\text { Completeness of } \\
\text { Environmental } \\
\text { Change Material }\end{array}$ & 4 & Very valid \\
\hline 16. & $\begin{array}{l}\text { Digital Literacy } \\
\text { Aspects }\end{array}$ & 4 & Very valid \\
\hline
\end{tabular}

\begin{tabular}{clcl}
\hline Num. & $\begin{array}{c}\text { Assessment } \\
\text { Aspects }\end{array}$ & $\begin{array}{c}\text { Mode of } \\
\text { Score }\end{array}$ & Category \\
\hline $17 . \quad \begin{array}{l}\text { Supporting } \\
\text { Features of Digital } \\
\text { Literacy }\end{array}$ & 4 & Very valid \\
\hline Language & & \\
$18 . \quad$ Use of Language & 4 & Very valid \\
$19 . \quad$ Language & 4 & Very valid \\
& Structure & & Very valid \\
20. & Terms of Use & 4 & Very valid \\
\hline \multicolumn{2}{c}{ Overall Interpretation } & 4 & \\
\hline
\end{tabular}

Some of the suggestions and feedback provided by the validators are presented in Table 4 .

Table 4. Recapitulation of the Validators Suggestions and Feedback on E-flipbook

\begin{tabular}{ll}
\hline Num. & \multicolumn{1}{c}{ Suggestions and Feedback } \\
\hline 1. & E-flipbook is well used to retrieve data. \\
\hline 2. & $\begin{array}{l}\text { Change the use of themes in the Google Form } \\
\text { header, hence, it is similar to the flipbook and } \\
\text { changes the expired source (renamed the } \\
\text { website). }\end{array}$ \\
\hline
\end{tabular}

The e-flipbook was responded to by five senior high school biology teachers as users getting mode 4 grades in a very practical category (Table 5). It also showed that this e-book can be used as additional teaching material for students. 
Table 5. Opinions of Teachers as Users on the Quality of E-Flipbook $(n=5)$

\begin{tabular}{|c|c|c|c|}
\hline Num. & $\begin{array}{c}\text { Assessment } \\
\text { Aspects }\end{array}$ & $\begin{array}{l}\text { Mode } \\
\text { Score }\end{array}$ & Category \\
\hline \multicolumn{4}{|l|}{ Design } \\
\hline 1. & Display Quality & 4 & Very practical \\
\hline 2. & Layout Quality & 4 & Very practical \\
\hline 3. & Text Quality & 4 & Very practical \\
\hline 4. & Figure Quality & 4 & Very practical \\
\hline 5. & Video Quality & 4 & Very practical \\
\hline 6. & $\begin{array}{l}\text { E-flipbook } \\
\text { Quality }\end{array}$ & 4 & Very practical \\
\hline \multicolumn{4}{|c|}{ Content } \\
\hline 7. & $\begin{array}{l}\text { Quality of } \\
\text { Material } \\
\text { Concepts }\end{array}$ & 4 & Very practical \\
\hline 8. & $\begin{array}{l}\text { Title of E- } \\
\text { flipbook }\end{array}$ & 4 & Very practical \\
\hline 9. & Introduction & 4 & Very practical \\
\hline 10. & $\begin{array}{l}\text { Instructions for } \\
\text { Use of E- } \\
\text { flipbook }\end{array}$ & 4 & Very practical \\
\hline 11. & $\begin{array}{l}\text { Characteristics } \\
\text { of E-flipbook }\end{array}$ & 4 & Very practical \\
\hline 12. & Content & 4 & Very practical \\
\hline 13. & References & 4 & Very practical \\
\hline 14. & Glossary & 4 & Very practical \\
\hline 15. & $\begin{array}{l}\text { Completeness of } \\
\text { Environmental } \\
\text { Change Material }\end{array}$ & 4 & Very practical \\
\hline 16. & $\begin{array}{l}\text { Digital Literacy } \\
\text { Aspects }\end{array}$ & 4 & Very practical \\
\hline 17. & $\begin{array}{l}\text { Supporting } \\
\text { Features of } \\
\text { Digital Literacy }\end{array}$ & 4 & Very practical \\
\hline No. & $\begin{array}{l}\text { Assessment } \\
\text { Aspects }\end{array}$ & $\begin{array}{l}\text { Mode } \\
\text { Score }\end{array}$ & Category \\
\hline \multicolumn{4}{|c|}{ Language } \\
\hline 18. & $\begin{array}{l}\text { Use of } \\
\text { Language }\end{array}$ & 4 & Very practical \\
\hline 19. & $\begin{array}{l}\text { Language } \\
\text { Structure }\end{array}$ & 4 & Very practical \\
\hline 20. & Terms of Use & 4 & Very practical \\
\hline Over & all Interpretation & 4 & Very practical \\
\hline
\end{tabular}

Some of the suggestions and feedback provided by the practitioners for the environmental change e-flipbook are presented in Table 6.

Table 6. Recapitulation of the Practitioners Suggestions and Feedback on E-flipbook

\begin{tabular}{cl}
\hline Num. & \multicolumn{1}{c}{ Suggestions and Feedback } \\
\hline 1. & $\begin{array}{l}\text { Update issues raised with more recent ones / } \\
\text { up-to-date on the "Mari Berliterasi" feature } \\
\text { to increase students' interest in reading, and } \\
\text { add some practice questions to the "Ayo } \\
\text { Berlatih" to make it more meaningful. }\end{array}$ \\
\hline $2 . \quad \begin{array}{l}\text { Revise multiple doublewords to delete, and } \\
\text { change the color composition of the flipbook } \\
\text { by giving the dominant green leaf color. }\end{array}$ \\
\hline $3 . \quad \begin{array}{l}\text { Adding video links, experiment on } \\
\text { environmental change material to increase } \\
\text { students' creativity and knowledge to apply } \\
\text { the material. }\end{array}$ \\
\hline
\end{tabular}

\begin{tabular}{cl}
\hline Num. & \multicolumn{1}{c}{ Suggestions and Feedback } \\
\hline 4. & $\begin{array}{l}\text { The e-flipbook is very useful in study and } \\
\text { work-at-home situations because it is } \\
\text { supported by videos, images, and examples } \\
\text { that are around. It also trains students to } \\
\text { titrate, find knowledge to answer problems } \\
\text { and conclude the material. This can be } \\
\text { developed for other materials. }\end{array}$ \\
\hline 5. & $\begin{array}{l}\text { Add a display via mobile phone on the } \\
\text { instructions for using the e-flipbook to make } \\
\text { it easier for students to study anytime. }\end{array}$ \\
\hline
\end{tabular}

According to the results of the student response questionnaire, the majority responded very well with an overall percentage average of 95\% (Table 7). It also showed the e-book can be used by students to learn practically.

Table 7. Recapitulation of Student's Responses

\begin{tabular}{clcl}
\hline No. & \multicolumn{1}{c}{$\begin{array}{c}\text { Assessment } \\
\text { Aspects }\end{array}$} & $\begin{array}{c}\text { Mode } \\
\text { Score }\end{array}$ & Category \\
\hline 1. & $\begin{array}{l}\text { E-flipbook } \\
\text { appearance }\end{array}$ & 96 & Very good \\
2. & E-flipbook operation & 96 & Very good \\
3. & Interest in e-flipbook & 92 & Very good \\
4. & Content & 95 & Very good \\
5. & Digital literacy & 96 & Very good \\
& competencies & & \\
& according to Gilster \\
& & \\
\hline & Overall Average & 95 & Very good \\
\hline
\end{tabular}

Some students responded through the comments and suggestions column contained in the response questionnaire as presented in Table 8.

Table 8. Recapitulation of Student Comments and Suggestions on E-flipbook

\begin{tabular}{clc}
\hline No. & Suggestions and Feedback & $\begin{array}{c}\text { Percentage } \\
(\%)\end{array}$ \\
\hline 1. & $\begin{array}{l}\text { The e-flipbook cover should } \\
\text { be made more attractive }\end{array}$ & 5 \\
\hline 2. & $\begin{array}{l}\text { This e-flipbook can train } \\
\text { students to choose which news } \\
\text { are hoaxes or trusted }\end{array}$ & 20 \\
\hline 3. & $\begin{array}{l}\text { Increase the pictures and } \\
\text { videos }\end{array}$ & 15 \\
\hline 4. & Nice and interesting & 30 \\
\hline 5. & No comment & 30 \\
\hline
\end{tabular}

Normalized gain score results (Table 9), showed students experienced an increase in high category digital literacy on technical skills indicators and also had an increase in the medium category on critical understanding, as well as communicative abilities indicators. This showed the e-flipbook can train students' digital literacy. 
Table 9. The Increase of Digital Literacy Based on Normalized Gain Scores

\begin{tabular}{ccccc}
\hline Indicator & $\begin{array}{c}\text { Pre- } \\
\text { test } \\
(\boldsymbol{\%})\end{array}$ & $\begin{array}{c}\text { Post- } \\
\text { test } \\
(\boldsymbol{\%})\end{array}$ & $(\mathbf{g})$ & Category \\
\hline $\begin{array}{c}\text { Internet } \\
\text { searching }\end{array}$ & 5 & 78 & 0.8 & High \\
\hline $\begin{array}{c}\text { Hypertextual } \\
\text { navigation }\end{array}$ & 10 & 77.5 & 0.8 & High \\
\hline $\begin{array}{c}\text { Content } \\
\text { evaluation }\end{array}$ & 14.6 & 73.5 & 0.7 & Medium \\
\hline $\begin{array}{c}\text { Knowledge } \\
\text { assembly }\end{array}$ & 24.5 & 67 & 0.6 & Medium \\
\hline Average & & & 0.7 & Medium \\
\hline
\end{tabular}

The e-flipbook on environmental change topic was used to train digital literacy. Moreover, the books are specifically designed textbooks using electronic devices and can be accessed through computers or other gadgets (Tosun, 2014). It contains a series of the topic's concepts and components such as images, videos, and hyperlinks. The advantages of multimedia images, videos, or hyperlinks that combine to convey messages are effective for students because a lot of information is obtained (Sezgin \& Ulus, 2017).

Also, the material has features that can practice digital literacy. These features refer to competencies formulated by Giltser (1997) including internet searching, hypertextual navigation, content evaluation, and knowledge assembly. This is in line with Ambarwati et al. (2019) and Putri \& Ambarwati (2019b), which stated that digital literacy can be improved and trained by achieving competency of internet searching, hypertext direction guides, information content evaluation, and knowledge complication.

Based on the analysis results, the e-flipbook was considered to be valid in terms of the validity results with the feasibility aspects of design, content, and language. The first aspect was the feasibility of the design which obtained a valid category. The validity results of the design feasibility are also in line with the response of the practitioner (teacher) who stated that it was considered to be very practical and followed the good presentation criteria. This is because the developed e-flipbook fulfilled the six assessment components, namely the display quality, layout, text, images, video, and e-flipbook quality. The quality component of an e-flipbook layout can be seen from its size and type. Furthermore, it has a B5 size with a display that can be flipped (back and forth), hence, it looked simple and attractive. This is in line with the opinion of Fitriyani et al. (2017), which stated that e-books can be flipped like real books, give interesting impressions and direct the attention of students. According to Susanti (2013), textbooks categorized as good and appropriate to use are presented in an interesting form, hence, students can understand all the contents and material presented.

The second aspect is the content feasibility to obtain a valid interpretation based on the validation results. This is directly proportional to the response of practitioners (teachers) that obtained a very practical category. This is because the e-flipbook fulfilled the content feasibility assessment including the quality of the material concept, systematic suitability of e-flipbook writing, completeness of environmental change material, digital literacy competence, and supporting features of digital literacy. According to Muslich (2010), content validity should fulfill several things including the suitability of the material with basic competency, its accuracy, as well as the learning support material.

The e-flipbook material is the most important thing in understanding students' concepts, therefore they should be relevant, systematically structured, and practice various activities (Prastowo, 2015). Furthermore, it contains a description of concepts that are systematically compiled and discussed environmental changes, their causes, and their impact on life. In addition to this concept, there are audio-visual media to facilitate understanding in studying the topic because it is a very interesting form of content taught to students in online learning during the Covid-19 pandemic. Foutsitzi (2018) stated that the use of this media concept provides change and experience in the learning process because the images are not static but animated, therefore, it has more graphic advantages and is seen as an attractive medium. This is supported by Surasmi (2016), which stated that the use of video 
as an additional medium helps to clarify and understand concepts.

Some of the hyperlink information contains content about changes and pollution to the environment, as well as waste recycling. The information presented can facilitate students to visit the web page provided to add content related to the material given (Susilawati, 2016). Besides, eflipbook features can also encourage students to further broaden their knowledge to understand the content. This is in line with Mardhiyana (2017) which stated that learning is not just about understanding concepts but can be explored for further clarity.

The third aspect is language feasibility to obtain a valid interpretation because the language used follows the students' development level according to the Bahasa Indonesia rules as well as italics for words in foreign languages. The language component is a means of delivery that includes discourse, sentences, paragraphs, and vocabulary. This is supported by Nurlaili (2011), which stated that when the use of sentence structure is clear, it will be easier for students to understand the material being taught.

The recapitulation results of the teacher's response to the e-flipbook also support the validation results of obtaining a very practical interpretation. The response became one of the determinants of practicality on environmental change e-flipbook. The involvement of teachers in responding to e-book is needed, given their important role in selecting and determining appropriate teaching materials to assist students in achieving competence (Kantun \& Budiawati, 2015). Furthermore, one of their responses as an eflipbook user stated that it was very practical as teaching materials for an online class given the current learning and working situations at home. Therefore, it is important to create innovative ideas to realize more effective online learning during the Covid-19 pandemic (Darmalaksana et al., 2020).

The pandemic condition requires all teachers to change learning patterns. The only choice of the learning system that can be applied is online. Therefore, the developed e-flipbook to train digital literacy is one of the learning resources that can help in conveying learning to students in the current state. This was supported by Sanjaya (2020) that online classes will help in implementing learning during emergencies because technology can be a bridge for teachers in transferring knowledge to students.

E-flipbook validity was also directly proportional to its practicality in terms of student responses. Based on the analysis results, the eflipbook was considered very good in terms of appearance, operation, interest, content material, and digital literacy competence. Regarding every aspect, all students responded very well.

However, in one component of digital literacy competence (hypertextual navigation), there are still students who did not respond positively, this is because they were first trained to browse the web and were still in the process of getting used to it. According to Ting (2015), students are currently familiar with digital technology and generally only know how to access, create, and share digital information. Nevertheless, Greene et al. (2014) stated that for digital literacy, a person does not only need to find and manage but also study and integrate digital information. This ability can be trained through the e-flipbook.

Besides, the material effectiveness was also measured using pre-test and post-test digital literacy aspects. The results showed each digital literacy indicator increased according to the normalized gain score (Table 10). The average percentage of students' pre-test scores on this aspect was classified as a low level. Furthermore, the results indicated that students did not gain preliminary knowledge about digital literacy on environmental change topics and also had a low level of understanding due to a lack of prior knowledge about digital literacy. Shepherd \& Tello (2015) stated that a material delivered by the teacher will be fully understood by students when they have gained related preliminary knowledge. Therefore, initial knowledge is important for students to understand material concepts.

After learning how to use the e-flipbook, the digital literacy ability of students increased based 
on post-test scores. This is because students had studied the material which includes features that facilitated them to train digital literacy skills. Also, the ability of this skill is different because each student's understanding level related to digital literacy was taught differently, and influenced by various factors. Lee et al. (2015) stated that student environmental factors are related to scores and digital literacy levels. According to Jan (2018), students who are accustomed to processing technology have high digital literacy.

Based on digital literacy competencies according to Gilster (1997), internet searching and hypertextual navigation showed that 10th-grade students were at a high level (advanced) after reading environmental change e-flipbook. This means the process of finding information can be effective due to clear and systematic guidelines, as well as navigation links in the book. This is in accordance with Embong et al. (2012) that good ebook contains a hypertext link navigation, multimedia objects, and technology access guides students. Also, the information presented in the eflipbook is a spreading phenomenon in the community. The use of phenomena that occur in society on features that facilitate digital literacy can also be applied to other learning for easy understanding.

Vast majority of students were able to choose a trusted website based on education domains, for example as .edu and .ac.id. Also, they answered correctly when given false information. Metzger \& Flanangin (2013) stated that an evaluation of the online information is carried out to determine whether it is trustworthy or not. Based on the features found in each e-flipbook chapter, students are trained to elaborate their search results in written form, therefore, they were able to evaluate well.

Meanwhile, on the competence of knowledge assembly, 10th-grade students were at the medium level after reading the environmental change eflipbook. This revealed that processing and building the collection of information in the form of facts and opinions were still needed to be familiarized with students. Several students gave incomplete answers and were less active in developing their knowledge by searching for other sources of information. According to Moreno \& Park (2009), students who had high prior knowledge will easily integrate various elements of complex information with existing schemes. Also, Ngilawajan (2013) showed information processing by students was carried out by linking information received with the knowledge they had. Therefore, strong initial knowledge will help build or combine information and students need to be familiarized to processing information online for a rapid increase in abilities.

\section{CONCLUSION}

According to the results on the development of e-flipbook on environmental change topic to train digital literacy, it can be concluded that the validity test obtained a very valid category. Furthermore, the practicality test had a practical and good category, while its effectiveness test was declared effective with a high category. Therefore, the e-flipbook to train digital literacy in the 10thgrade senior high school was valid, practical, and effective, hence it is feasible to be applied in learning.

Further studies on the application of eflipbook on a broader scale need to be conducted to determine the effectiveness of direct learning in the classroom and to ascertain student activities in working on the e-book features.

\section{ACKNOWLEDGMENTS}

The authors are grateful to Dr. Sunu Kuntjoro, M.Si., Muji Sri Prastiwi, S.Pd., M.Pd., dan Dr. Raharjo, M. Si. as validators who reviewed and validated the e-flipbook. The authors are also grateful to the biology teachers and students who gave valuable comments and responses.

\section{REFERENCES}

Ambarwati, R., Faizah, U., \& Rahayu, D.A. (2019). Enhancing the Digital Literacy of Pre-Service Biology Teacher through Animal Systematics Course. Journal of Advance in Computer Science Research, 95, 197-201. 
Darmalaksana, W., Hambali, R.Y.A., Masrur, A. \& Muhlas. (2020). Analisis Pembelajaran Online Masa WFH Pandemic Covid-19 sebagai Tantangan Pemimpin Digital Abad 21. Karya Tulis Ilmiah (KTI) Masa Work From Home (WFH) Covid-19 UIN Sunan Gunung Djati Bandung, 1-12.

Embong, A.M., Noor, A.M., Hashim, H.M., Ali, R.M., \& Shaari, Z.H. (2012). E-Books as textbooks in the classroom. Procedia-Social and Behavioral Sciences, 47, 1802-1809.

Fitriyani., Muhaimin., \& Rusdi, M. (2017). Pembelajaran Menggunakan Media 3D Pageflip Professional dan Media Camtasia Studio 8 pada Materi Larutan Elektrolit dan Non Elektrolit di Kelas X SMA Islam AlArief Muaro Jambi. Respiratory University of Jambi, 2(1), 1-9.

Foutsitzi, A. (2018). Images in Educational Textbooks and Educational Audiovisual Media. European Journal of Language and Literature, 10(2), 30.

Gilster, P. (1997). Digital Literacy. New York: Wiley.

Greene, J.A., Yu, S.B., \& Copeland, D.Z. (2014). Measuring Critical Components of Digital Literacy and their Relationships with Learning. Computers \& Education, 76, 5569.

Gumilar, G., Justito, A., \& Nunik, M. (2017). Literasi Media: Cerdas Menggunakan Media Sosial Dalam Menanggulangi Berita Palsu (Hoax) Oleh Siswa SMA. Pengabdian Kepada Masyarakat, 1(1), 35-40.

Hake, R. R. (1999). Analyzing Change/Gain Scores (Online).

(www.physics.indiana.edu/ sdi/AnalyzingC hangeGain.pdf, accessed on 22 April 2020).

Haris, D. (2011). Panduan Lengkap E-book: Strategi Pembuatan dan Pemasaran E-book. Jakarta: Cakrawala.

Holland, A. A. (2019). Effective Principles of Informal Online Learning Design: A Theory
Building Meta-synthesis of Qualitative Research. Computers \& Education, 1-34.

Jan, S. (2018). Gender, School, and Class-wise Differences in Level of Digital literacy among Secondary School Students in Pakistan. Issues and Trends in Educational Technology, 6(7), 15-27.

Kantun, S., \& Budiawati, Y.S.R. (2015). Analisis Tingkat Kelayakan Bahan Ajar Ekonomi yang Digunakan Oleh Guru di SMA Negeri 4 Jember. Jurnal Pendidikan Ekonomi, 9(2), 129-146.

Khasanah, U., \& Herina. (2019). Membangun Karakter Siswa Melalui Literasi Digital Dalam Menghadapi Pendidikan Abad 21 (Revolusi Industri 4.0). Prosiding Seminar Nasional Pendidikan Program Pascasarjana Universitas Pgri Palembang. (Accessed on 20 February 2020).

Lee, S., Kim, J., \& Lee, W. (2015). Analysis of elementary students' ICT literacy and their self-evaluation according to their residential environments. Indian Journal of Science and Technology, 8(1), 81-88.

Litbang Kemdikbud. 2013. Kurikulum 2013: Pergeseran Paradigma Belajar Abad-21. (Online) (http://litbang.kemdikbud.go.id/inde x.php/index-beritakurikulum/243kurikulum2013-pergeseranparadigmabelajar-abad-211, accessed on 20 February 2020).

Mardhiyana, D. (2017). Upaya Meningkatkan Rasa Ingin Tahu Mahasiswa Melalui Penerapan Pembelajaran Berbasis Proyek pada Mata Kuliah Evaluasi Proses dan Hasil Pembelajaran Matematika. Jurnal Ilmiah Pendidikan Matematika, 5(1), 1-8.

Metzger, M.J., \& Flanangin, A.J. (2013). Credibility and trust of information in online environments: The use of cognitive heuristics. Journal of Pragmatics, 59, 210220.

Moody, A. K. (2010). Using Electronic Book in the Classroom to Enhance Emergent Literacy Skills in Young Children. Journal of Literacy and Technology, 11(4), 22-25. 
Moreno, R., \& Park, B. (2009). Cognitive Load Theory: Historical Development and Relation to Other Theories. In J. Plass, R. Moreno \& R. Brunken (Eds.). Cognitve load theory, Newyork: Cambridge University Press.

Muslich, M. (2010). Text Book Writing. Jakarta: Ar-rus Media.

Ngilawajan, A. D. (2013). Proses berpikir siswa SMA dalam memecahkan masalah matematika materi turunan ditinjau dari gaya kognitif field independent dan field dependent. Pedagogia, 2(1), 71-83.

Nurlaili. (2011). Pengukuran Tingkat Keterbacaan Wacana dalam LKS Mata Pelajaran Bahasa Indonesia Kelas 4-6 SD dan Keterpahamiannya. Jurnal Universitas Pendidikan Indonesia (UPI), Vol. Khusus (1), 167-177.

Partnership for 21st Century Learning. (2015). Framework for 21st Century Learning. (Online) (www.p21.org/, accessed on 4 February 2020).

Prastowo, A. (2015). Panduan Kreatif Membuat Bahan Ajar Inovatif: Menciptakan Metode Pembelajaran yang Menarik dan Menyenangkan. Yogyakarta: Diva Press.

Pujiyanto, S. (2008). Menjelajah Dunia Biologi. Solo: Tiga Serangkai.

Putri, I.D.T. \& Ambarwati, R. (2019a). Analisis Konten Literasi Digital dalam Buku Ajar Biologi Materi Animalia. Prosiding Seminar Nasional Biologi IP2B III. Universitas Negeri Surabaya.

Putri, I.D.T. \& Ambarwati, R. (2019b). An effort in Teaching Invertebrates and Training Digital Literacy to the Students. Journal of Physics, 1417(1), 1-9.
Sanjaya, R. F. (2020). 21 Refleksi Pembelajaran Daring di Masa Darurat. Semarang: Universitas Katolik Soegijapranata.

Sezgin, E.Y., \& Ulus, L. (2017). The Early Literacy at Preschool Education: The Book or the E-Book?. TOJET: The Turkish Online Journal of Educational Technology, 16(4), 77-83.

Shepherd, C., \& Tello, A. (2015). Differentiating Instruction: As Easy as One, Two, Three. ERIC, 12(2), 95-100.

Surasmi, W. A. (2016). Pemanfaatan Multimedia Untuk Mendukung Kualitas Pembelajaran. Prosiding Tети Ilmiah Nasional Guru (Ting), 8, 593-607.

Susanti, R. D. (2013). Studi Analisis Materi Ajar "Buku Teks Pelajaran" pada Mata Pelajaran Bahasa Arab di Kelas Tinggi Madrasah Ibtidaiyah. Jurnal Arabia, 5(2), 199223.

Susilawati, S. (2016). Penggunaan Model Pembelajaran Hypertext dan Hypermedia dengan Blended Learning Terhadap Hasil Belajar. J-PIPS, 2(2), 143-160.

Ting, Y. (2015). Tapping into Students' Digital Literacy and Designing Negotiated Learning to Promote Learner Autonomy. Internet and Higher Education, 26, 25-32.

Tosun, N. (2014). A Study on Reading Printed Books or EBooks: Reasons for Studentteacher Preferences. The Turkish Online Journal of Educational Technology, 13(1), 21-28.

Wijaya, E.Y., Sudjimat, D.A., \& Nyoto, A. (2016). Transformasi Pendidikan Abad 21 Sebagai Tuntutan Pengembangan Sumber Daya Manusia di Era Global. Prosiding Seminar Nasional Pendidikan Matematika 2016 Universitas Kanjuruhan Malang (hal. 263278). Malang: Universitas Kanjuruhan Malang. 